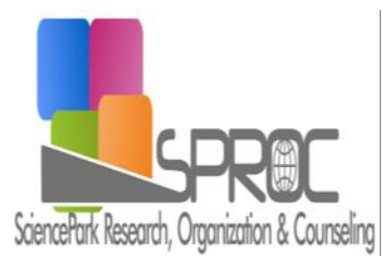

\title{
Successful eating self-regulation: a social cognitive perspective
}

Andreea-Mirela Mandia *

Suggested Citation:

Proceedings on Humanities and Social Sciences.

New Trends and Issues

J

Abstract

J 
1. Introduction

1.1. Literature review 


\section{Discussion}

$p$ 


\section{Conclusions and future study}

\section{Acknowledgements}

Social foundations of thought and action

Organizational Behavior And Human

Decision Processes 50

J J J K

9

Eating Behaviors,

Preventive Medicine, 30

$\mathrm{K}$

California Journal of Health Promotion, 7

Handbook of self-regulation : Research, theory, and applications 
Trends in Cognitive Sciences, 16,

K J

J

Obesity, 20

J

Association 63
Health Communication 24
241,

K J J

K

Health Communication 24

- Journal Of Pakistan Medical

$\mathrm{K}$

Acta endocrinologica 11 